\title{
Potential Consequences of Reforming Medicare Into a Competitive Bidding System
}

\section{Citation}

Song, Zirui, David M. Cutler, and Michael E. Chernew. 2012. "Potential Consequences of Reforming Medicare Into a Competitive Bidding System." JAMA 308 (5) (August 1): 459. doi:10.1001/jama.2012.7909.

\section{Published Version}

doi:10.1001/jama.2012.7909

\section{Permanent link}

http://nrs.harvard.edu/urn-3:HUL.InstRepos:32306635

\section{Terms of Use}

This article was downloaded from Harvard University's DASH repository, and is made available under the terms and conditions applicable to Other Posted Material, as set forth at http:// nrs.harvard.edu/urn-3:HUL.InstRepos:dash.current.terms-of-use\#LAA

\section{Share Your Story}

The Harvard community has made this article openly available.

Please share how this access benefits you. Submit a story.

\section{Accessibility}




\section{Potential Consequences of Reforming Medicare Into a Competitive Bidding System}

Zirui Song, PhD

David M. Cutler, PhD

Michael E. Chernew, PhD

T HE IDEA OF A PREMIUM SUPPORT (OR VOUCHER) SYStem for Medicare has generated substantial debate. Under premium support, Medicare beneficiaries would choose from health plans that compete in a market-based bidding system. In some models, traditional Medicare is abandoned entirely in favor of private health plans. In other models such as the Ryan-Wyden plan, traditional Medicare becomes one option among many.

Proponents of premium support cite 2 potential strengths. First, competition may lower health care spending. Second, by pegging the Medicare contribution to one of the lowercost plans and limiting the increase in the government's contribution over time, public spending on Medicare will slow. ${ }^{1}$ Critics state that bidding essentially shifts costs to beneficiaries by increasing their required premiums. ${ }^{2}$

Competitive bidding is not new to Medicare. The Medicare Advantage (MA) program has used bidding to determine plan payments since 2006. In MA, plans submit a price (bid) they are willing to accept to insure a beneficiary. Payment is determined by comparing the bid with a benchmark payment rate set by Medicare (published annually online), based on the counties the plan serves. If the bid exceeds the benchmark, Medicare pays the plan the benchmark rate and the plan must collect the difference by charging a premium to enrollees. If the bid undercuts the benchmark, the plan is paid its bid plus $75 \%$ of the difference (a rebate), which it must return to enrollees via extra benefits or lower premiums. Currently, more than $90 \%$ of MA plans offer some kind of rebate to attract enrollees.

Based on the Ryan-Wyden plan, the bidding system proposed in the recent House Republican budget replaces the administratively set benchmark with a market-determined benchmark. ${ }^{3}$ In every county, either the plan with the second-lowest bid or traditional Medicare (whichever is lower) becomes the benchmark. Thus, every beneficiary would have at most 1 lower-cost option. Any beneficiary choosing a plan (including traditional Medicare) that bids above the benchmark must pay the difference between that plan's bid and the benchmark out of pocket.

An estimate of what such a bidding system may mean for Medicare beneficiaries, using 2006-2009 data on MA plan bids and traditional Medicare costs, is shown in the TABLE. Nationally, in 2009, the benchmark plan under the Ryan-Wyden framework (ie, the second-lowest plan) bid an average of 9\% below traditional Medicare costs (traditional Medicare was equivalent to approximately the tenth-lowest bid). Since traditional
Medicare is simply another plan option under the Ryan-Wyden plan, a beneficiary in 2009 would have paid an average of $\$ 64$ per month (9\% of $\$ 717$ ) in additional premiums to stay in traditional Medicare. Across the United States, $68 \%$ of traditional Medicare beneficiaries in 2009 (approximately 24 million beneficiaries) lived in counties in which traditional Medicare spending was greater than the second-least expensive plan and would have paid more to keep their choice of coverage (a share that would have been $81 \%$ in $2008,75 \%$ in 2007 , and $67 \%$ in 2006 ). Furthermore, more than $90 \%$ of MA beneficiaries (approximately 6.6 million seniors, excluding those dually eligible or in employer plans) would have also paid more for the plan they chose.

Private plans can cost less than traditional Medicare because: (1) they may use medical resources more efficiently; (2) they may enroll healthier patients relative to the riskadjusted payment; or (3) their negotiated prices may not fully reflect the costs of indirect medical education or payments for disadvantaged hospitals, which traditional Medicare explicitly pays. The magnitudes of efficiency, selection, and avoided add-on payments are unclear; debate over whether add-on payments should be included in the traditional Medicare amount for bidding purposes is ongoing. To the extent that the $9 \%$ cost advantage reflects efficiency, it suggests there are better ways to provide the traditional Medicare benefit. Indeed, if plans are bidding above their cost of insuring beneficiaries, the 9\% gap may underestimate the full efficiency gain.

Affordable Care Act (ACA) reforms to traditional Medicare may change these estimates by moving traditional Medicare toward improved incentives for cost and quality through accountable care organizations, bundled payments, and strengthening primary care. ${ }^{5}$ The ACA also aims to slow the growth of traditional Medicare costs by reducing fee increases for some health care institutions. If traditional Medicare costs slow but do not close the $9 \%$ gap entirely, as currently projected, millions of beneficiaries will still have to pay more, although less than $\$ 64$ per month, to maintain their choice of coverage-assuming the benchmark stays the same. However, if the ACA reduces traditional Medicare costs enough so that traditional Medicare becomes the benchmark, beneficiaries would no longer pay more to keep traditional Medicare; instead, MA plans would be costlier than traditional Medicare and require a premium.

These estimates may have potential implications for policymakers. Specifically, if competition or the ACA does not lower

Author Affiliations: Department of Health Care Policy (Drs Song and Chernew), and Francis Weld Peabody Society (Dr Song), Harvard Medical School, Boston; National Bureau of Economic Research, Cambridge (Drs Song, Cutler, and Chernew); and Department of Economics, Harvard University, Cambridge (Dr Cutler), Massachusetts. Corresponding Author: Zirui Song, PhD, Harvard Medical School, 180 Longwood Ave, Boston, MA 02115 (zirui_song@hms.harvard.edu). 
Table. Lowest Plan Bids vs Traditional Medicare Costs, 2006-2009a

\begin{tabular}{|c|c|c|c|c|c|c|}
\hline \multirow[b]{2}{*}{ Year } & \multirow[b]{2}{*}{ Average Traditional Medicare Costs, \$/mo } & \multicolumn{5}{|c|}{ Average Plan Bid, \% of Traditional Medicare Costs } \\
\hline & & Lowest & Second-Lowest ${ }^{b}$ & Third-Lowest & Fourth-Lowest & Fifth-Lowest \\
\hline 2009 & 717 & 87 & 91 & 94 & 95 & 96 \\
\hline 2008 & 721 & 82 & 87 & 89 & 91 & 91 \\
\hline 2007 & 705 & 84 & 89 & 92 & 94 & 95 \\
\hline 2006 & 699 & 82 & 88 & 90 & 93 & 94 \\
\hline
\end{tabular}

a Based on Medicare Advantage plan payment data and actual fee-for-service Medicare spending data. ${ }^{4}$ All costs are adjusted to 2009 US dollars.

b Under the Ryan-Wyden plan, the second-lowest bidding private health plan in a county (or the county's traditional Medicare costs, whichever is lower) serves as the benchmark. All plans bidding above the benchmark must charge beneficiaries a premium equal to the difference between the plan's bid and the benchmark. The lowest-bidding private plan, in counties in which traditional Medicare is not the lowest bidder, would offer a rebate to plan beneficiaries.

the benchmark, a bidding system such as the Ryan-Wyden plan faces the prospect of millions of Medicare beneficiaries being asked to pay more for the coverage in which they are currently enrolled. The estimates in the Table are broadly consistent with a prior analysis, ${ }^{6}$ although approximately 2.5 million more beneficiaries in this estimate would have paid more to stay in traditional Medicare compared with the prior report, which used aggregated estimates of the 25th percentile of bids as the benchmark, rather than actual plan bids used in this analysis. The estimate of the $\$ 64$ per month ( $9 \%$ of $\$ 717$ ) in additional premiums that traditional Medicare beneficiaries would pay may also be higher than in the prior report, although a direct comparison is not possible. For high-income seniors, paying more may not be problematic. For low-and moderate-income seniors however, $\$ 64$ per month could be very significant. Additional premium support for low-income seniors would help, but likely would not make up the difference.

Moreover, incentivizing beneficiaries to join private Medicare plans, even if less expensive, may have undesirable effects. In particular, reliance on beneficiary shopping to discipline the market has been problematic. Beneficiaries are often slow to switch plans due to cognitive impairment, choice overload, consumer inertia, or other influences. For example, Medicare Part D plans, which also operate in a bidding system, have found it profitable to price low initially, attract many enrollees, then increase prices over time. ${ }^{7}$ Moreover, beneficiaries do not enroll in Part D plans that offer them the best coverage for their premiums and medical conditions. ${ }^{8}$ These market failures would likely be even greater in a market-based Medicare system in which choosing plans would likely be even more difficult than in Part D. The market requires beneficiaries to trade restrictions on care or limited physician networks for premiums, which is counter to how many seniors view Medicare.

Premium support, based on competitive bidding, may offer a fiscal solution if ACA reforms fail, but at the cost of making Medicare beneficiaries responsible for solving Medicare's fiscal crisis. Success of the ACA can make premium support less risky by lowering traditional Medicare costs and helping to monitor and improve quality in private plans. Without ACA improvements, beneficiaries must pay more for traditional Medicare or join a private plan. Given the current fiscal pressures, this may be acceptable, but it is a major shift from traditional Medicare that may have deleterious consequences.
Conflict of Interest Disclosures: Dr Song reports receipt of institutional support from a National Institute on Aging (NIA) Predoctoral MD/PhD National Research Service Award and a Predoctoral Fellowship in Aging and Health Economics from the National Bureau of Economic Research (NBER). Dr Cutler reports having served on the Council of Economic Advisers and the National Economic Council during the Clinton Administration; nomic Advisers and the National Economic Council during the Clinton Administration; consulting services as an advisory board member to Fidelity Biosciences and Genentech; receipt of past institutional grants from the Social Security Administration (SSA) and NIA/ AmER, and current institutional grants from the Peterson Foundation to the Center for American Progess and NIA/NBER, receipt of a research grant from the Kaiser Family Foundation; receipt of lecture or speakers bureau fees from VHA Inc, International Monetary Fund, care Financial Management Association, Delaware Health Society, InHealth Summit, Medforce, Novartis, Novartis Spain, Partners' Connected Health Symposium, Siemans Healthcare, World Health Care Congress, American College of Physician Executives, America's Health Insurance Plans, CareSource, ChainDrugStore.net, Federal Reserve Bank of Chicago, Forces for Change-America's Health Insurance Plans, Healthcare Financial Management Association, IMS Consulting, Med Impact Healthcare Systems, Medtronic, National Association of Drug Stores, Society of Actuaries, Thomson Reuters, US Oncology, Brokers and Reinsurance Markets Association, The Capital Group Companies, Marcus Evans, National Pharmaceutical Council, Real Colegi Computense, University of Washington, and Warburg Pincus; compensation as coeditor for the Journal of Health Economics; receipt of the MetLife Silver Scholar Award; membership with the Institute of Medicine, the National Academy of Social Insurance, and the Institute for Research on Poverty; serving as a research associate with NBER; receipt of honoraria for writing papers or organizing conferences for NBER; being a fellow for the Employee Benefit Research Institute; and receipt of book royalties for Your Money or Your Life. Dr Chernew reports being vice chair on the Medicare Payment Advisory Commission, and a health advisor to the Congressional Budget Office; paid board memberships with The Commonwealth Fund, Congressional Budget Office, Abbott, FairHealth, Value-Based Insurance Design Institute, CMS technical adviFffice, Abbott, FairHealth, Value-Based Insurance Design Institute, CMS technical advisory panel, Benefit-Based Designs, Pfizer; nonpaid board memberships with Health Research \& Educational Trust, North Carolina Prevention Partner Advisory Council on EvidenceBased Incentives and Benefits, Massachusetts Medical Society, Coalition for Health Services Research; consultancies with Trizetto, sanofi, Massachusetts Medical Society, America's Health insurance Plans, Genentech, Thomson Reuters, Robert Wood Johnson Foundation, Hewit, Johnson \& Johnson, Altarum, Excellus, Avalere, Blue Cross Blue Shield; 列 hearing; an institutional grant or pending grant from the NIA, Universal American, Pfizer, The Commonwealth Fund, payment for manuscript preparation from Avalere, Blue Cross Blue Shield, Precision Health Economics, New America Foundation, London School of Economics; travel/accommodations/meeting expenses unrelated to activities listed from Texas A\&M University, University of Chicago, Duke University, University of Toronto, Pennsylvania State University, Tilburg University, Yale School of Management, University of Pennsylvania, University of Southern California, American Enterprise Institute, Bureau of Economic Analysis, Engelberg Center for Health Care Reform, Chapter of Public Health \& Occupational Physicians, Illinois Hospital Association; and editor for the Health Services Research Journal and the American Journal of Managed Care.

Funding/Support: This work was funded by a grant P01 AG032952 from the the NIA

\section{REFERENCES}

1. Antos JR. The Wyden-Ryan proposal. N Eng/ J Med. 2012;366(10):879-881.

2. Aaron HJ, Frakt AB. Why now is not the time for premium support. N Engl J Med. 2012;366(10):877-879.

3. House Budget Committee. Fiscal Year 2013 Budget Resolution: the Path to Prosperity - a Blueprint for American Renewal. http://budget.house.gov/UploadedFiles /Pathtoprosperity2013.pdf. Accessed: May 28, 2012.

4. Centers for Medicare and Medicaid Services. Plan Payment Data. http://www .cms.gov/Medicare/Medicare-Advantage/Plan-Payment/Plan-Payment-Data .html. Accessed: April 28, 2012.

5. Dept of Health and Human Services and Centers for Medicare \& Medicaid Services. Medicare shared savings program; accountable care organizations-final rule. 2011. http://www.gpo.gov/fdsys/pkg/FR-2011-11-02/pdf/2011-27461.pdf. Accessed: May 27, 2012.

6. Feldman R, Coulam R, Dowd B. Competitive bidding can help solve Medicare's fiscal crisis. http://www.aei.org/files/2012/02/16/-competitive-bidding-can-helpsolve-medicares-fiscal-crisis_081704430956.pdf. Accessed: June 1, 2012.

7. Ericson KMM. Market design when firms interact with inertial consumers. 2011 http://www.bu.edu/econ/files/2009/07/Ericson-Paper-MedicarePartD-Aug11 .pdf. Accessed: April 28, 2012

8. Abaluck J, Gruber J. Choice inconsistencies among the elderly. Am Econ Rev. 2011; 101(4):1180-1210. 